Martin D. Henry (ITQ, vol. 70/4, 2005, 362)

\title{
Christianity and Anti-Semitism
}

Matricide is an awe-inspiring crime. To kill another human being is vile enough, to kill one's own mother, to deprive of life the person who gave one life, is to move into a different dimension of horror. It represents an almost metaphysical assault on the very order of reality. Yet, if scholars are correct who tell us that Christianity sprang from Judaism, then Christian anti-Semitism, which has frequently in the course of history not stopped short of murder, could be interpreted as a form of matricide, of religious or, at least, religiously inspired matricide.

That religion should inspire murder is, of course, nothing new. Indeed the first recorded murder in the Bible has a specifically religious dimension. Cain killed Abel, we are told, out of envy: Abel and his offerings found favour with God, whereas Cain and his offerings didn't (cf. Gen 4. 3-5). Yet making all due allowances for the power of envy and other unlovely human passions, it is still quite puzzling to be confronted with a religion teaching love even of one's enemies, veering off eventually into matricide. Perhaps the question of identity might provide a clue to illuminate this murky mystery.

While many will commit crime for fear of poverty, psychologists assure us that the most insidiously dangerous kind of poverty is to be deprived of one's identity. The recent, and perhaps still unfinished, conflict in Northern Ireland is often claimed to be about the protagonists' sense of their own identity, rather than simply a sordid squabble over land and power. Or rather, the latter, while real, is only the expression of a deeper need. It is only the means by which a deeper need can be satisfied: the need to preserve and reinforce the identity one would like to coincide with and parade before the world.

What has any of this to do with Christian anti-Semitism? In all likelihood, quite a lot. According to its own self-understanding, Christianity is not merely the fulfilment of Judaism, but Judaism should have transformed itself, without remainder, into Christianity. Judaism, in its entirety, should have recognized and accepted Christ as the promised Messiah. That this manifestly did not happen, is undisputed. Rather, Judaism, in its large majority, continued on its historical way, declining the offer to 
join the Christian Church. The upshot of Christianity's failure to absorb Judaism has been that Judaism has continued historically to be, as it were, a thorn in Christianity's flesh, a constant, uneasy reminder to Christianity that its claims may not be true, at least not in any self-evident or readily comprehensible sense.

Historically, Judaism has been Christianity's bad conscience, an unremitting, silent threat to the substance of Christianity's identity. Is it imaginable, then, that Christians, over and over again, could have been, and still could be, tempted to remove the thorn from their flesh, to stifle the fear and suspicion of possible error in their own self-understanding, by attempting to kill, and indeed potentially to wipe out all memory of, those whose continued existence was and remains an implicit question to the legitimacy of Christianity's claims? Is the need for identity so imperious in human beings that they will stop at nothing in order to satisfy it? Ironically, the socalled 'Jewish question' may, after all, really be the 'Christian question'. 